\title{
The perceived value and perceived benefits experienced by customers using travel agents
}

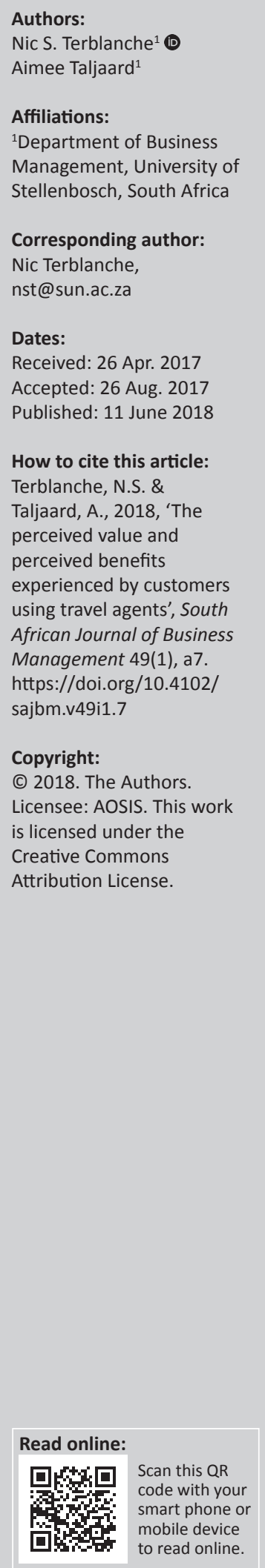

Although many predictions have been made about the demise of travel agents because of the impact of the Internet on travel agencies, many customers still prefer that a travel agent should take care of their travel arrangements instead of doing it themselves. This study endeavours to identify the benefits customers perceive to obtain when they use a travel agent for their travel arrangements. The exploratory and confirmatory factor analyses following the personal in-depth interviews with 26 customers of a travel agency and an extensive literature review revealed significant positive relationships between four perceived benefits and customer loyalty. These perceived benefits were identified as financial benefits, emotional benefits, expertise and support. An assessment of the internal consistency of all these dimensions was undertaken and all the Cronbach's alpha coefficients of the dimensions were above the generally accepted cut-off value of 0.7 . The structural model's fit statistics $\left(\mathrm{X}^{2}=349.27 ; \mathrm{df}=125 ; \mathrm{X}^{2} / \mathrm{df}=2.79 ; \mathrm{RMSEA}=0.0548\right)$ suggested that the data fitted the theoretical model reasonably well.

\section{Introduction}

Brick-and-mortar travel agencies have been affected by advances in information and communication technology and by the widespread use of the Internet in the planning and purchasing of travel trips. The extent to which the Internet has affected brick-and-mortar travel agencies in favour of online travel agencies differs substantially among countries and market segments. The Bureau of Statistics in the United States reported that full-time travel agents in the United States decreased substantially from 124000 in 2000 to around 74000 in 2014 (Lam 2016; McCarthy 2016). In Western Europe, the number of bookings through brick-and-mortar travel agencies reduced from 33\% to 20\% between 2008 and 2012. Olenski (2015) adds that half of the Australian travellers who travel overseas prefer the personal contact of brick-and-mortar travel agencies for their travel arrangements. Although there has been a substantial decline in the number of these travel agencies, some have survived by developing personal relationships with customers in niche markets (McCarthy 2016; Oates 2015). In a recent study of 27 European countries, it was found that travel agents are still an important source of information for travellers (Korneliussen \& Greenacre 2017). On average, 11.4\% of the respondents consulted a travel agent for travel information, with Austrian respondents reporting the highest (17.6\%) and Hungarian respondents reporting the lowest (5.7\%) use of travel agents as sources of information (Korneliussen \& Greenacre 2017). No reliable figures are available with respect to the effect that the Internet has had on travel agencies in South Africa. However, the South African Association of Travel Agents has recently stated that the number of travel agencies is on the increase again and that travel bookings through travel agents are on the rise as well (ASATA 2016). As indicated earlier, many customers still prefer the services of a travel agent. For the purposes of this article, a brick-andmortar travel agent is a personal travel agent that assists an individual with the purchasing of retail services or products. Although some of the activities of the brick-and-mortar travel agents may be online, the interaction with such agents can be on a personal face-to-face level in a physical building that is owned or rented.

\section{Research background, objectives and structure of the article}

Since the 1990s, many predictions have been made about the disintermediation of the brick-andmortar travel agencies that will be replaced by online travel agencies and the online travel-related reservation facilities offered by, for instance, airlines, hotels and resorts. The primary objective of this research was to determine why some customers, despite the popularity of online use for the shopping of travel services, still prefer to leave shopping of travel services to travel agents. The primary objective was thus to identify the value and benefits that travel agents offer to customers, 
which make travel agents preferable to online shopping for travel services. The second objective was to determine which perceived benefits have a positive relationship with customer loyalty. Thereafter, we report on a qualitative study during which a sample of frequent South African travellers was interviewed to identify the perceived benefits obtained when shopping for travel services with travel agents. In order to address these objectives, a review of the theory and literature that relates to perceived value and perceived benefits is provided.

The context of our study is perceived value and perceived benefits experienced by customers who use travel agents. Rational customer behaviour is to get the most out of the utility from an exchange process by maximising benefits and minimising costs (Hasan et al. 2017). Customer costs would typically include financial, temporal and physical costs (Markin 1979). Benefits, in contrast, refer to what is received, such as goods and services (Konovsky \& Pugh 1994). Where costs exceed the benefits, customers will walk away from a deal; conversely, if the benefits exceed the costs, it is expected that rational customers will remain loyal (Settoon, Bennett \& Liden 1996).

Much has been published on the advantages and benefits of people doing their own bookings, comparing prices and shopping for travel services online (Amaro \& Duarte 2015; Nunkoo \& Ramkissoon 2013; Wang et al. 2016). Although online shopping for travel services has become popular, there are still customers who prefer to leave the shopping for travel services to travel agents. Some customers prefer that travel agents do their travel arrangements instead of doing the travel arrangements themselves. These customers do so as the perceived benefits offered by travel agents exceed the costs of making their own arrangements. This phenomenon of the trade-off between perceived benefits and costs is explained well by the social exchange theory. This theory denotes that individuals' social behaviour is the outcome of an exchange process (Lawler \& Thye 1999).

\section{Literature review: Perceived value and perceived benefits}

Since the 1990s, the customer perceived value concept and its contribution to consumer purchase intention and subsequent loyalty have received extensive coverage in the literature (Bove \& Johnson 2002; Cronin et al. 2000; Slater 1997; Slater \& Narver 1994; Sweeney \& Soutar 2001; Woodruff 1997). Overall perceived value can be described as a subjective construct that will differ between consumers, between cultures and over time (Sabiote-Ortiz, Frías-Jamilena \& Castañeda-García 2016). Perceived value has also been acknowledged in marketing research as central to the understanding of consumer behaviour (Nilson 1992; Ostrom \& Iacobucci 1995). Hollebeek (2013) notes that perceived value has been referred to in various theoretical and contextual applications, including relationship marketing (McColl-Kennedy et al. 2008), the service dominant logic literature (Gummesson 2008; Woodruff \& Flint 2006) and in other areas such as hospitality (Oh 1999) and e-commerce settings (Chen \& Dubinsky 2003). Extensive research has been undertaken on the conceptualisation of perceived value. In a shopping value context, Babin, Darden and Griffin (1994) distinguish between utilitarian and hedonic value dimensions and all the factors, qualitative and quantitative, subjective and objective, that make up the complete shopping experience. Utilitarian (extrinsic) value represents the instrumental benefits of shopping (i.e. buying a particular item or service), while hedonic (intrinsic) value signifies experiential benefits emanating directly from the shopping experience itself (i.e. fun, novelty, escape) (Babin \& Darden 1995). In a comprehensive review of the perceived value concept, Sánchez-Fernández and Iniesta-Bonillo conclude that the concept implies an interaction between a customer and a product or service; that perceived value is relative by virtue of its comparative, personal and situational nature; and that perceived value is preferential, perceptual and cognitive-affective in nature (2007). Recently Kumar and Reinartz (2016:37) defined perceived value as 'customers' net valuation of the perceived benefits accrued from an offering that is based on the costs they are willing to give up for the needs they are seeking to satisfy'. They concur with Gutman (1982) that the perceived customer value of an offering is the combination of both the benefits that a customer seeks, expects or experiences and the unexpected consequences that come with the benefits. The vital aspect of their conceptualisation of perceived value is that customers 'choose actions that, ceteris paribus, maximize the desired consequences and minimize concurrent undesired consequences' (Kumar \& Reinartz 2016:37). The benefits of an offering, as well as all the undesired consequences, are created by the offering of attributes. Gutman (1982) explains the differences between benefits and attributes, namely, that customers receive benefits, whereas an offering consists of attributes. Plewa, Sweeney and Michayluk (2015) argue that perceived value is equivalent to value-in-use, as perceived value is what emerges from or is created by the customer after interactions between the customer and the service provider.

\section{Personal interviews with customers who travel frequently}

Since the extant literature offers little guidance about the perceived benefits offered by travel agents to customers, we conducted interviews with people who travel frequently to identify the benefits they perceive they obtain when using a travel agent. A travel agent was requested to supply names of customers who travel frequently and who would be suitable to interview for this study, and who would be willing to participate. The travel agent obtained the consent of the customers to take part in the interviews before we approached them to schedule the interviews. Personal in-depth interviews were conducted with 26 customers. This sample of respondents consisted of 10 males and 16 females, with their ages ranging from 22 to 69 years. The interviewees were given a brief description of what the study entailed and what the concept of perceived benefits meant. The interviewees 
then shared their views about the perceived benefits they experienced and which they felt were important when a travel agent proposed and booked a trip for them. The interviews were recorded and transcribed. The transcripts were read and analysed for coding. A categorisation process was followed to identify themes that recurred in the data. Words that reflected similar characteristics were grouped together to identify common descriptors that characterised each theme and to develop a definition for each theme. The following themes occurred most times in the transcribed text (the number in brackets indicate how many times a word(s) were used in a particular context):

1. Experience and knowledge of travel agents (53)

2. Assistance, support and advice provided by travel agents (48)

3. A positive emotional relationship with the travel agent (42)

4. Customisation and planning arrangements to a customer's needs (33)

5. Ability to find suitable and affordable financial offerings (27)

6. Convenience of not having to spend own time on searches (17)

The categorisation process identified six recurring themes. Based on the perceived benefits that emerged from the literature review and in-depth interviews, the six perceived benefits were identified as those perceived by customers when they use travel agents to do their travel arrangements for them. These perceived benefits were convenience, customisation, expertise, support and financial and emotional benefits. These six perceived benefits were classified as the dimensions of the value construct for customers who use travel agents to do their travel arrangements. Anisimova (2007) found that functional consumer benefits are the most consistent predictors of both attitudinal and behavioural loyalty. Appendix 1 contains a number of typical customer comments made during the personal interviews.

\section{Perceived convenience benefits}

Berry, Seiders and Grewal (2002:4) conceptualise service convenience as 'consumers' time and effort perceptions related to buying or using a service'. Mimouni-Chaabane and Volle (2010) view convenience as reducing choice, and saving time and effort. Berry (1995) believes that the benefit of convenience is to reduce or simplify the risk of decisionmaking. Gwinner, Gremler and Bitner (1998) found that the non-monetary benefits of time-saving also result from not having to search for another service provider. For the purposes of this study, the concept perceived convenience benefits is defined as the ease of concluding a transaction; the simplification of complicated itineraries; and easy decisionmaking to save time and effort. Based on the preceding discussion, the following is hypothesised:

H1: Perceived convenience benefits have a positive relationship with customer loyalty.

\section{Perceived customisation benefits}

Various authors have suggested that customised offerings can have a considerable effect on the way a consumer perceives the value of an offering, as the customised offerings can simplify the decision-making process and also convey more related benefits of using the service (Broekhuizen \& Alsem 2002; Gazley, Hunt \& McLaren 2015; Zarrad \& Debabi 2012). Gwinner et al. (1998:105) assert that the 'customisation benefit can include the customer's perception of preferential treatment, extra attention or personal recognition, and special service not available to other customers'. For the purposes of this study, perceived customisation benefits refer to a product or service that is tailor-made to a customer's demands. It is therefore hypothesised that:

H2: Perceived customisation benefits have a positive relationship with customer loyalty.

\section{Perceived expertise benefits}

The three basic components of perceived expertise benefits are training, knowledge and experience (Business Dictionary 2017). Expertise is necessary to match product offerings to customer needs and expectations (Dampérat \& Jolibert 2009). Furthermore, for professional services such as those offered by a travel agent, seller expertise is considered as 'product quality' and therefore seller expertise is the core element that customers seek when considering to buy a service of this nature (Wan et al. 2012). In this study, perceived expertise benefits include the opinions, advice, recommendations and answers to customers' questions and receiving relevant and accurate information. Given this reasoning, it is hypothesised that:

H3: Perceived expertise benefits have a positive relationship with customer loyalty.

\section{Perceived financial benefits}

The financial benefits of retail shopping have been operationalised as value motivations in the form of looking for sales, discounts and bargains (Arnold \& Reynolds 2003). For the purpose of this study, perceived financial benefits are defined as money-saving, the best money deals given budget constraints, value for money and avoiding unexpected expenses by being informed of all costs before any financial commitment is made. Based on the preceding discussion, it is hypothesised that:

H4: Perceived financial benefits have a positive relationship with customer loyalty.

\section{Perceived emotional benefits}

The benefits of hedonic value offered by the interaction with a travel agent are experiential, emotional and symbolic in nature (Holbrook \& Hirschman 1982). The inseparability characteristic of services and the interaction between the customer and supplier in the service exchange process leads to a shared responsibility towards the outcome, resulting in intensified emotions. When these heightened 
emotions are positive, they lead to increased customer loyalty to the service provider (Sierra \& McQuitty 2005). Positive emotional experiences by a customer interacting with a travel agent ultimately contribute to customer satisfaction that support customers' decisions to be loyal to a particular travel agent (Lam et al. 2004). We therefore hypothesise that:

H5: Perceived emotional benefits have a positive relationship with customer loyalty.

\section{Perceived support benefits}

In marketing, seller support refers to the integration of people, processes, technology and strategies that combine organisational resources and communication to enable customer value creation interactions. Seller support makes it possible for customers to access the services they want, when and how they want them (Nilsson 2007). On an individual level, perceived support benefits denote the extent to which a service provider shows consideration for a customer because the focus is on the dyadic relationship between the two (Yi \& Gong 2013). Perceived support benefits are operationalised to include having a specific person to provide assistance, to solve problems that may arise and who can personally attend to customer complaints, cancellations, refunds and alterations. Against this background, it is hypothesised that:

H6: Perceived support benefits have a positive relationship with customer loyalty.

\section{Customer loyalty}

Although there is no consensus definition of loyalty, previous research generally demonstrates that it represents a mix of attitudes and behaviours that benefit one firm relative to its competitors (Dick \& Basu 1994; Melnyk, van Osselaer \& Bijmolt 2009; Watson et al. 2015). A considerable amount of existing theories frequently demarcate attitudinal loyalty and behavioural loyalty as the primary elements of customer loyalty (Watson et al. 2015). Customer loyalty, as an intangible asset, benefits a retailer in various ways. Customer loyalty, in terms of its attitudinal and behavioural dimensions, presents substantial opportunities for differentiation and as a foundation for a competitive advantage (Cossío-Silva et al. 2016). The consequences of customer loyalty are extensively recognised in the marketing literature (El-Manstrly 2016). A tiny increase in customer loyalty has a considerable impact on a firm's financial value, and loyal customers are inclined to purchase more (Lam \& Burton 2006; Roos \& Gustafsson 2007). In addition, loyal customers are more profitable, are more tolerant with respect to service failures, are resilient to competitors' products and services and need less effort to retain (Ganesh, Arnold \& Reynolds 2000; Narayandas 2005; Reichheld 1996; Yi \& La 2004). For the purposes of this research, the following definition of Watson et al. (2015:803) is used to portray customer loyalty, namely, that 'customer loyalty is a collection of attitudes aligned with a series of purchase behaviours that systematically favour one entity over competing entities'.

\section{The relationship between perceived benefits by customers and customer loyalty}

The relationship between the benefits that customers perceive and loyalty as an outcome thereof has been studied by various researchers. Hennig-Thurau, Gwinner and Gremler (2002) investigated the relationship between confidence benefits, social benefits, special treatment benefits and loyalty. In the Hennig-Thurau et al. (2002) study, confidence benefits and social benefits had a significant relationship with loyalty. Dagger, David and Ng (2011) studied the role that commitment plays in driving customer loyalty and in identifying the effect that confidence, social and special treatment benefits have on the development of commitment, and ultimately customer loyalty. Their findings indicate that to enhance customer loyalty (via customer commitment), firms have to provide confidence, social and special treatment benefits to their customers. Kuo and Feng (2013) studied the effect that hedonic, social, and learning benefits have on community commitments. They found that hedonic, social and learning benefits have a positive effect on community commitments and ultimately customer loyalty. Lin, Lobo and Leckie (2017) investigated consumers' perceptions of a brand's green benefits (GPV) and brand loyalty and found that the influence of GPV on brand loyalty was significant. Chen and $\mathrm{Hu}$ studied customer loyalty in the highly competitive Australian coffee outlet market and found that relational benefits have a direct positive effect on customer loyalty. In a somewhat different perspective, MimouniChaabane and Volle (2010) investigated the benefits of loyalty programmes in various industries that appeal to customers. They found that both monetary and nonmonetary benefits, such as monetary savings, exploration, entertainment, recognition and social benefits, that loyalty programmes offer appeal to customers. It is therefore evident that it can be expected that benefits that customers perceive have a positive relationship with their loyalty to a firm.

Figure 1 illustrates the hypothesised relationships of the perceived benefits with customer loyalty.

\section{Methodology}

The methodology that was followed consisted of questionnaire development, sampling, data collection and the statistical analyses of the data.

\section{Questionnaire development}

All six perceived benefits dimensions and the items measuring them were subjected to an assessment by a marketing research practitioner and senior marketing academics to ensure content validity of the questionnaire and items for a study in a travel agency setting. All the items in the questionnaire were measured on a 10-point Likert scale, where 1 represented 'strongly disagree' and 10 represented 'strongly agree'. The questionnaire comprised 38 items in total, of which 32 measured the six perceived benefits and six 


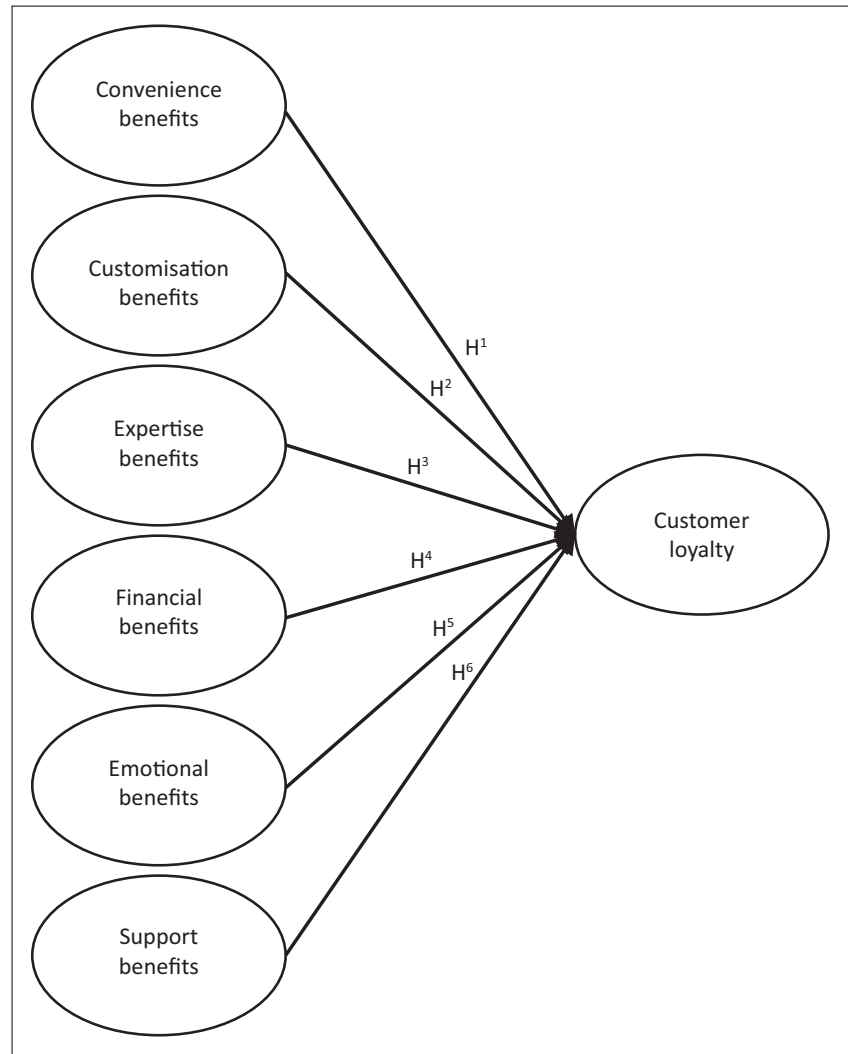

FIGURE 1: The hypothesised relationships of the perceived benefits with customer loyalty.

items measured customer loyalty, customer satisfaction and reputation (customer satisfaction and reputation were measured for purposes of nomological validity). All the questionnaire items emerged from the literature review and the in-depth interviews with customers. The final items that were used for data collection as well as their supportive sources are listed in Appendix 2.

\section{Sample and data collection}

The sample of the study consisted of South African respondents who travelled frequently and who used a specific airline. A random sample consisting of 5000 travellers was drawn from the airline's database of frequent travellers. An online questionnaire was e-mailed to all members of the sample and a total of $599(11.9 \%)$ fully completed questionnaires were received. The majority of the respondents, namely $418(69.8 \%)$, had been using a travel agent for more than 10 years. The respondents also made use of a travel agent on a fairly regular basis as $402(67.1 \%)$ of them indicated that they had used a travel agent more than four times a year. Table 1 contains the details of the respondents.

\section{Statistical analyses}

An exploratory factor analysis was undertaken to test whether a relationship existed between the perceived benefits and the items measuring them. The sample for the exploratory analysis consisted of 599 respondents who had travelled frequently. The IBM SPSS statistics programme version 24
TABLE 1: Particulars of the respondents.

\begin{tabular}{|c|c|c|c|}
\hline \multirow[t]{2}{*}{ Variable } & \multicolumn{3}{|c|}{ Gender } \\
\hline & Male & Female & Total \\
\hline \multicolumn{4}{|l|}{ Age category } \\
\hline $20-30$ & 5 & 8 & 13 \\
\hline $31-40$ & 61 & 38 & 99 \\
\hline $41-50$ & 143 & 43 & 186 \\
\hline $51-60$ & 150 & 47 & 197 \\
\hline $60+$ & 89 & 15 & 104 \\
\hline Total & 448 & 151 & 599 \\
\hline \multicolumn{4}{|c|}{ Number of years a travel agent was used } \\
\hline $1-2$ years & 6 & 6 & 12 \\
\hline $3-5$ years & 39 & 20 & 59 \\
\hline $6-10$ years & 73 & 37 & 110 \\
\hline$>10$ years & 330 & 88 & 418 \\
\hline Total & 448 & 151 & 599 \\
\hline \multicolumn{4}{|c|}{ Number of times using a travel agent } \\
\hline Once a year & 32 & 23 & 55 \\
\hline Twice a year & 37 & 23 & 60 \\
\hline Three times a year & 33 & 12 & 45 \\
\hline Four times a year & 28 & 9 & 37 \\
\hline$>$ Four times a year & 318 & 84 & 402 \\
\hline Total & 448 & 151 & 599 \\
\hline \multicolumn{4}{|l|}{ Purpose of travel } \\
\hline Leisure & 15 & 18 & 33 \\
\hline Business & 116 & 25 & 141 \\
\hline Leisure/business & 317 & 108 & 425 \\
\hline Total & 448 & 151 & 599 \\
\hline
\end{tabular}

was used for this purpose. For the exploratory analysis, the factor extraction setting was Principal Axis Factoring with Direct Oblimin rotation. The exploratory analysis revealed four factors with factor loadings above 0.40 and which accounted for $81.79 \%$ of the variance in the data. These four factors were then labelled 'perceived financial benefits', 'perceived emotional benefits', 'perceived expertise benefits' and 'perceived support benefits'. The study thus could not support the dimensions 'perceived convenience benefits' or the 'perceived customisation benefits' that were identified during the interviews and the literature review. Only one customisation item was loaded with two expertise items to form an expertise benefit factor. The items provided strong contributions to the factor they represented (factor loadings ranged from 0.410 to 0.957$)$. Tables 2 and 3 provide more details on the results of the exploratory factor analysis.

A confirmatory factor analysis was then conducted using LISREL 8.80 (Jöreskog \& Sörbom 2006) to assess the measurement properties of the items used in the model. As it emerged that the data were not normally distributed, the Robust Maximum-Likelihood (RML) estimation method was used to test the theoretical model. Table 4 summarises the model fit statistics of the measurement model and suggests that it fits the data reasonably well (RMSEA $=0.0548 ; \mathrm{X}^{2} / \mathrm{df}$ ratio $=2.79$ ).

An assessment was made of the internal consistency of all the dimensions. All the Cronbach alpha coefficients of the dimensions were above the generally accepted cut-off value of 0.7 (Nunnally \& Bernstein 1994). The reliability results are reported in Table 5. 
TABLE 2: Results of the exploratory factor analysis.

\begin{tabular}{llcccc}
\hline Factor names & Items & \multicolumn{4}{c}{ Pattern matrixa : Factor } \\
\cline { 3 - 6 } & & $\mathbf{1}$ & $\mathbf{2}$ & $\mathbf{3}$ & $\mathbf{4}$ \\
\hline Perceived financial benefits & Fin5 & 0.957 & 0.000 & 0.057 & 0.009 \\
& Fin4 & 0.878 & 0.006 & 0.074 & 0.050 \\
& Fin1 & 0.871 & 0.014 & 0.054 & 0.016 \\
& Fin6 & 0.811 & 0.103 & 0.004 & 0.039 \\
& Fin2 & 0.799 & 0.062 & 0.121 & 0.079 \\
Perceived emotional benefits & Symb4 & 0.015 & 0.888 & 0.013 & 0.051 \\
& Symb7 & 0.026 & 0.886 & 0.035 & 0.037 \\
& Symb3 & 0.055 & 0.771 & 0.030 & 0.088 \\
& Symb5 & 0.027 & 0.730 & 0.178 & 0.042 \\
& Symb6 & 0.042 & 0.687 & 0.038 & 0.200 \\
& Supp4 & 0.001 & 0.007 & 0.884 & 0.012 \\
& Supp2 & 0.087 & 0.001 & 0.851 & 0.004 \\
& Supp1 & 0.017 & 0.118 & 0.683 & 0.075 \\
Perceived support benefits & Exper1 & 0.010 & 0.019 & 0.071 & 0.848 \\
& Cust1 & 0.062 & 0.042 & 0.012 & 0.833 \\
& Exper2 & 0.154 & 0.012 & 0.397 & 0.410 \\
\hline
\end{tabular}

Note: Extraction method: principal axis factoring; Rotation method: Oblimin with Kaise normalisation.

a, Rotation converged in 10 iterations.

TABLE 3: Results of the exploratory factor analysis: Factor correlation matrix perceived benefits

\begin{tabular}{lcccc}
\hline Perceived benefits & $\begin{array}{c}\text { Financial } \\
\text { benefits }\end{array}$ & $\begin{array}{c}\text { Emotional } \\
\text { benefits }\end{array}$ & $\begin{array}{c}\text { Support } \\
\text { benefits }\end{array}$ & $\begin{array}{c}\text { Expertise } \\
\text { benefits }\end{array}$ \\
\hline Financial benefits & 1.000 & 0.585 & 0.669 & 0.683 \\
Emotional benefits & 0.585 & 1.000 & 0.511 & 0.518 \\
Support benefits & 0.669 & 0.511 & 1.000 & 0.735 \\
Expertise benefits & 0.683 & 0.518 & 0.735 & 1.000 \\
\hline
\end{tabular}

Note: Extraction method: principal axis factoring; Rotation method: Oblimin with Kaiser normalisation.

TABLE 4: Fit indices of the measurement model.

\begin{tabular}{lc}
\hline Fit indices & Value \\
\hline Degrees of freedom & 125 \\
Minimum fit function chi-square & $477.591(p=0.0)$ \\
Satorra-Bentler scaled chi-square & $349.269(p=0.0)$ \\
$X^{2} / d f$ & 2.79 \\
RMSEA & 0.0548 \\
ECVI & 0.738 \\
NFI & 0.988 \\
\hline
\end{tabular}

RMSEA, root mean square error of approximation; ECVI, expected cross-validation index $\mathrm{NFI}$, normed fit index.

TABLE 5: Reliability results.

\begin{tabular}{lc}
\hline Dimension & $\boldsymbol{\alpha}$ \\
\hline Perceived financial benefits & 0.948 \\
Perceived emotional benefits & 0.919 \\
Perceived support benefits & 0.892 \\
Perceived expertise benefits & 0.902 \\
Overall & 0.952 \\
\hline
\end{tabular}

The next step of the data analysis process was to assess the relationships in the structural model using LISREL 8.80. The model fit statistics $\left(X^{2}=349.27 ; \mathrm{df}=125 ; X^{2} / \mathrm{df}=2.79 ; \mathrm{RMSEA}=\right.$ $0.0548)$ suggested that the data fitted the theoretical model reasonably well. The empirical results reported in Figure 2 show that Hypotheses 3, 4, 5 and 6 could not be rejected. In other words, a positive relationship was found between perceived financial benefits, perceived emotional benefits, perceived support benefits and perceived expertise benefits on the one hand, and customer loyalty on the other hand.

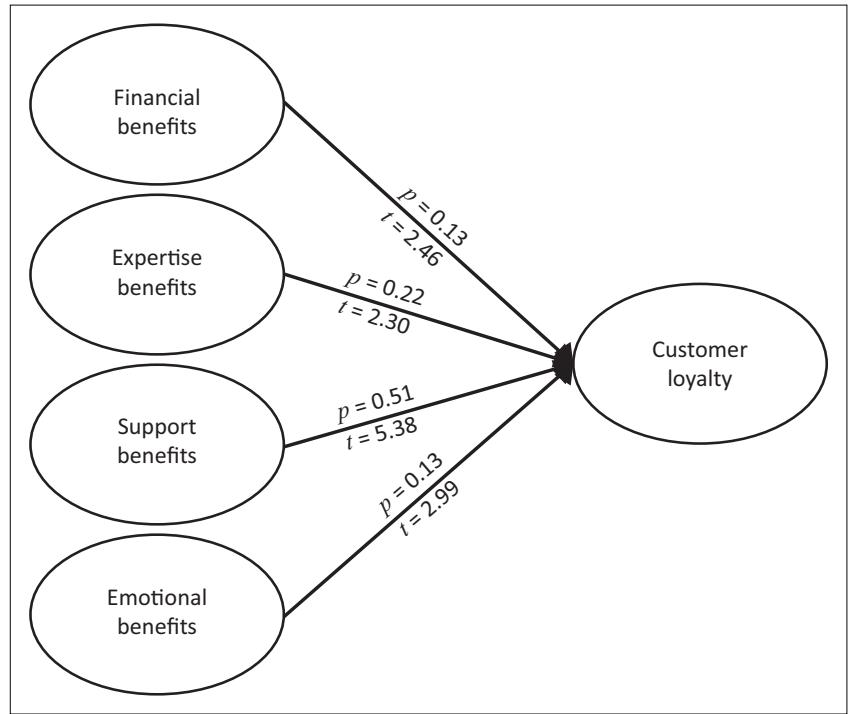

FIGURE 2: Empirical model.

TABLE 6: Items to measure the customer outcome variables.

Items Supporting source

Item that measured customer satisfaction:

Overall, I am satisfied with my travel agent. Wang et al. (2016)

Items that measured reputation:

My travel agent has a favourable reputation. Nguyen and Leblanc (2001)

My travel agent is highly reputable. del Bosque, Martín and Collado (2006)

I have never heard anything bad about my Schwaiger (2004)

travel agent.

Items that measured customer loyalty:

I am loyal to my travel agent.

Walsh, Beatty and Shiu (2009)

I have developed a good relationship with Walsh and Beatty (2007)

my travel agent.

To assess the nomological validity of the model, correlations were used to measure the strength of the relationships between the four perceived benefit dimensions and the related constructs of customer loyalty, satisfaction and overall reputation. These three measures were expected to be positively associated with the mentioned perceived benefits. To show that the perceived benefit measures have nomological validity, the correlation between the measures and other related constructs should behave as predicted in theory (Churchill 1995). The items that were used to measure the customer outcome measures (customer loyalty, satisfaction and overall reputation) were based on previously published items in the literature and are indicated in Table 6 . The reliability of the customer loyalty and overall reputation scales was assessed by means of Cronbach's alpha measures (varying between 0.869 and 0.942). The strength of the relationships between the perceived benefit dimensions and the customer outcome variables of customer satisfaction, customer loyalty and overall reputation are illustrated in Table 7. Given the predicted positive association between the four perceived benefit scales and the three customer outcome variables, correlations were examined to assess nomological validity. These correlations are provided in Table 7. All 12 correlations between the perceived benefit dimensions and the customer outcome variables were significant at $p<0.05$. These measures correlated in a manner predicted by theory, thus 
TABLE 7: Correlation matrix of the perceived benefit dimensions and the customer outcome variables.

\begin{tabular}{|c|c|c|c|c|c|c|c|}
\hline Variable & Expertise & Emotional & Financial & Support & Satisfaction & Loyalty & Reputation \\
\hline \multirow[t]{2}{*}{ Expertise } & 1 & $0.568^{*}$ & $0.712^{*}$ & $0.763^{*}$ & $0.835^{*}$ & $0.723^{*}$ & $0.695^{*}$ \\
\hline & 599 & 599 & 599 & 599 & 599 & 599 & 599 \\
\hline \multirow[t]{2}{*}{ Emotional } & $0.568 *$ & 1 & $0.598 *$ & $0.548^{*}$ & $0.560 *$ & $0.573^{*}$ & $0.519 *$ \\
\hline & 599 & 599 & 599 & 599 & 599 & 599 & 599 \\
\hline \multirow[t]{2}{*}{ Financial } & $0.712^{*}$ & $0.598^{*}$ & 1 & $0.658^{*}$ & $0.763^{*}$ & $0.663^{*}$ & $0.611 *$ \\
\hline & 599 & 599 & 599 & 599 & 599 & 599 & 599 \\
\hline \multirow[t]{2}{*}{ Support } & $0.763 *$ & $0.548^{*}$ & $0.658 *$ & 1 & $0.804 *$ & $0.744^{*}$ & $0.693 *$ \\
\hline & 599 & 599 & 599 & 599 & 599 & 599 & 599 \\
\hline \multirow[t]{2}{*}{ Satisfaction } & $0.835 *$ & $0.560^{*}$ & $0.763 *$ & $0.804 *$ & 1 & $0.805^{*}$ & $0.746 *$ \\
\hline & 599 & 599 & 599 & 599 & 599 & 599 & 599 \\
\hline \multirow[t]{2}{*}{ Loyalty } & $0.723 *$ & $0.573^{*}$ & $0.663 *$ & $0.744 *$ & $0.805 *$ & 1 & $0.717^{*}$ \\
\hline & 599 & 599 & 599 & 599 & 599 & 599 & 599 \\
\hline \multirow[t]{2}{*}{ Reputation } & $0.695 *$ & $0.519 *$ & $0.611 *$ & $0.693 *$ & $0.746 *$ & $0.717^{*}$ & 1 \\
\hline & 599 & 599 & 599 & 599 & 599 & 599 & 599 \\
\hline
\end{tabular}

*, Correlation is significant at the 0.01 level (2-tailed).

supporting nomological validity. Therefore, Hypotheses 3-6 failed to be rejected while Hypotheses 1 and 2 could not be accepted.

\section{Findings}

The Internet has been part of booking travel arrangements for almost three decades. Although the Internet has led to the disintermediation of travel agents on a large scale, some customers still prefer to book travel arrangements through travel agents. Apart from the perceived risks associated with the online environment, there are various other reasons why certain customers prefer travel agents to do their travel arrangements. During the personal interviews and the literature review, it became apparent that customers who use travel agents do so because of six perceived benefits they receive from the interaction with travel agents. In the online survey, only two of the six perceived benefits, namely, convenience and customisation, were not supported by the respondents. The statistical analyses of the study found a strong positive relationship between the four perceived benefits, namely, financial, emotional, expertise and support benefits, and customer loyalty. The items that were used to measure financial, emotional, expertise and support benefits appear in Appendix 3.

\section{Conclusions and managerial implications}

This research not only contributes to the body of knowledge of perceived value and perceived benefits but also advances our understanding of the relationship of these concepts with customer loyalty. The research also has useful implications for marketing managers and travel agency managers and their staff. In order to offer the desired perceived value, customers have to be convinced that the perceived benefits of the travel agent's offering must be at least equal to or greater than the total cost and/or sacrifices they would have to make when doing the travel arrangements themselves. A thorough understanding of this value and cost relationship and its influence on customers' purchase decisions is fundamental in the marketing task of travel agents.
In a service industry such as travel agencies, the association between perceived value and perceived benefits and a travel agent's offering is difficult to identify because of the intangibility of the service. Ideally, travel agents should endeavour to make the intangible tangible during their interactions with customers. Travel agents can offer a diversity of travel products and services to customers in combinations demanded by customers. In many instances, air tickets, accommodation reservations and land transport are part of a single travel arrangement. Such combinations of travel products and services provide travel agents the opportunity to match customers' expectations and travel experience. The offering of personalised services requires that travel agents are well-informed about the preferences of customers. One way to ensure that a travel agent is fully informed about a customer's preferences and how a particular travel trip was experienced is to personally communicate with a customer afterwards. The opportunity to reflect will not only give the travel agent valuable feedback for possible future transactions, but it is also likely to be appreciated by the customer that the travel agent cares. Essentially, an attempt or gesture like this raises the bar in favour of the travel agent when a customer might consider switching to another alternative for travel arrangements.

It is important to keep in mind that when perceived benefits have been received by customers, it may become an essential determinant of value or even entitlement by a customer in encounters that could follow. Because of the personal nature of the interaction between a customer and a travel agent, there should be opportunities to offer some form of gratitude to acknowledge the customer's support.

The perceived emotional benefits offer travel agents a great opportunity for customer involvement. Travel agents should encourage customers to participate in the perceived value creation process as customers are best aware of their own needs and preferences making it possible for travel agents to convert the perceived value offering into value-in-use (Plewa et al. 2015). Value-in-use is exclusive to the relationship between a travel agent and a customer and is a major advantage over competitors as the latter have little knowledge 
about the criteria used by customers to form an exclusive value-in-use perception of a particular travel agent's offering. Other advantages of involving the customer are related to reducing the risk perceived or obtaining customer approval for the service that is actually required.

As mentioned earlier, the acceptance and use of the Internet for travel services is increasing continuously and it is likely that the Internet will be part and parcel of future generations' preferred platform of choice when shopping for travel services. As far as current customers are concerned, it is important to ascertain how they became and remain customers of travel agents. Some older customers might be afraid to use technology for transactions, while younger customers might feel insecure about purchasing trips and therefore they use travel agents for their first travel arrangements until they gain enough confidence to do it themselves. It is understandable that both these groups are, from a travel agent's viewpoint, just 'temporary' customers until they either gain confidence or lose their fear of using technology for travel transactions. It is imperative that travel agents offer the perceived benefits with every interaction with customers during and after a trip, thereby adding value.

Spielmann, Laroche and Borges (2012) emphasise the importance of personal interaction in the customers' perception to enhance credibility in their relationships with travel agents. Most of the perceived benefits that were found to positively influence customer loyalty in the present study stemmed from the interactions between customers and travel agents. Staff should be prepared for these personal interactions to respond with authority and expertise to the typical issues or concerns that customers may raise during personal interactions.

Furthermore, it should be kept in mind that customers can easily switch from a travel agent to another if there were no psychological bonds in place. The delivery of value via the four perceived benefits provides travel agents with both tangible and intangible means to create and maintain lasting relationships with their customers.

We suggest that the value of any trip or travel experience for customers can be adequately captured by measuring their responses to all four perceived benefits. The continuous measurement of the perceived benefits will enable travel agents to monitor changes in their own performance on a longitudinal basis and to timely identify deviations that warrant rectification. The findings from such surveys can thus serve as input for the prioritisation of staff training.

Lastly, it could be to the advantage of travel agents and their customers to provide information that is easy to use and that is easily accessible on their websites. All brick-and-mortar travel agents already have some presence on websites, but any further information that could add value to a customer's experience with a travel agent should also be available on the website.

\section{Limitations and suggestions for future research}

Given the confines of this academic article, it was not possible to provide all the answers as to why certain customers prefer travel agents to do their travel arrangements instead of doing it themselves using the Internet. Future research could study differences between the benefits perceived by leisure travellers and business travellers and the relationship between such perceived benefits and customer loyalty. Furthermore, diverse segments may exist of customers who prefer travel agents to take care of their travel arrangements. A thorough knowledge of these customer segments would be useful to develop marketing strategies (based on the bundling of particular perceived benefits) to appeal to customers from the different segments. It might also be of value for travel agents to study the relationship between other positive customer outcomes such as word-of-mouth, future patronage intentions and the perceived benefits obtained.

\section{Acknowledgements Competing interests}

The authors declare that they have no financial or personal relationships that may have inappropriately influenced them in writing this article.

\section{Authors' contributions}

N.S.T. and A.T. contributed equally to this work.

\section{References}

Amaro, S. \& Duarte, P., 2015, 'An integrative model of consumers' intentions to purchase travel online', Tourism Management 46, 64-79. https://doi. org/10.1016/j.tourman.2014.06.006

Anisimova, T.A., 2007, 'The effects of corporate brand attributes on attitudinal and behavioural consumer loyalty', Journal of Consumer Marketing 27(7), 395-405. https://doi.org/10.1108/07363760710834816

Arnold, M.J. \& Reynolds, K.E., 2003, 'Hedonic shopping motivations', Journal of Retailing 79(2), 77-95. https://doi.org/10.1016/S0022-4359(03)00007-1

ASATA, 2016, The travel agent of the future, Association of South African Travel Agents, 21 October 2016, viewed 20 April 2017, from http://asata.co.za/thetravel-agent-of-the-future/

Auh, S., Bell, S.J., McLeod, C.S. \& Shih, E., 2007, 'Co-production and customer loyalty in financial services', Journal of Retailing 83(3), 359-370. https://doi. org/10.1016/j.jretai.2007.03.001

Babin, B.J. \& Darden, W.R., 1995, 'Consumer self-regulation in a retail environment', Journal of Retailing 71(1), 47-70. https://doi.org/10.1016/0022-4359(95)90012-8

Babin, B.J., Darden, W.R. \& Griffin, M., 1994, 'Work and/or fun: Measuring hedonic and utilitarian shopping value', Journal of Consumer Research 20(4), 644-656. https://doi.org/10.1086/209376

Berry, L.L., 1995, 'Relationship marketing of services - Growing interest, emerging perspectives', Journal of the Academy of Marketing Science 23(4), 236-245. https://doi.org/10.1177/009207039502300402

Berry, L.L., Seiders, K. \& Grewal, D., 2002, 'Understanding service convenience', Journal of Marketing 66(3), 1-17. https://doi.org/10.1509/jmkg.66.3.1.18505

Bock, D.E., Mangus, S.M. \& Folse, J.A.G., 2016, 'The road to customer loyalty paved with service customization', Journal of Business Research 69(10), 3923-3932. https://doi.org/10.1016/j.jbusres.2016.06.002

Boshoff, C., 1999, 'An instrument to measure satisfaction with transaction specific service recovery', Journal of Service Research 1(3), 236-249. https://doi. org/10.1177/109467059913005

Bove, L.L. \& Johnson, L.W., 2000, 'A customer-service worker relationship model', International Journal of Service Industry Management 11(5), 491-511. https:// doi.org/10.1108/09564230010360191

Broekhuizen, T.L.J. \& Alsem, K.J., 2002, 'Success factors for mass customization: A conceptual model', Journal of Market-Focused Management 5(1), 309-330.

Business Dictionary, 2017, Definition of expertise, viewed 13 April 2017, from http:// www.businessdictionary.com/definition/expertise.html 
Chen, Z. \& Dubinsky, A.J., 2003, 'A conceptual model of perceived customer value in e-Commerce: A preliminary investigation', Psychology and Marketing 20, 323 347. https://doi.org/10.1002/mar.10076

Churchill, G.A., 1995, Marketing research: Methodological foundations, Dryden Press, Hinsdale, IL.

Caro, L.M. \& Garcia, J.A.M., 2008, 'Developing a multidimensional and hierarchical service quality model for the travel agency industry', Tourism Management 29(4), 706-720. https://doi.org/10.1016/j.tourman.2007.07.014

Coelho, P.S. \& Henseler, J., 2012, 'Creating customer loyalty through service customization', European Journal of Marketing 46(3/4), 331-356. https://doi. org/10.1108/03090561211202503

Colwell, S.R., Aung, M., Kanetkar, V. \& Holden, A.L., 2008, 'Toward a measure of service convenience: Multiple-item scale development and empirical test', Journa of Services Marketing 22(2), 160-169. https://doi.org/10.1108/0887604081 0862895

Cossío-Silva, F.-J., Revilla-Camacho, M.-A., Vega-Vázquez, M. \& Palacios-Florencio, B. 2016, 'Value co-creation and customer loyalty', Journal of Business Research
$69(5), 1621-1625$. https://doi.org/10.1016/j.jbusres.2015.10.028

Cronin, J.J., Jr., Brady, M.K. \& Hult, G.T.M., 2000, 'Assessing the effects of quality, value, and customer satisfaction on consumer behavioral intentions in service environments', Journal of Retailing 76(2), 193-218. https://doi.org/10.1016/ environments', Journal

Dagger, T.S., David, M.E. \& Ng, S., 2011, 'Do relationship benefits and maintenance drive commitment and loyalty?', Journal of Services Marketing 25(4), 273-281. hittps://doi.org/10.1108/08876041111143104

Dampérat, M. \& Jolibert, A., 2009, 'A dialectical model of buyer-seller relationships', Journal of Business \& Industrial Marketing 24(3/4), 207-217. https://doi. org/10.1108/08858620910939750

del Bosque, I.A.R., Martin, H.S. \& Collado, J., 2006, 'The role of expectations in the consumer satisfaction formation process: Empirical evidence in the travel agency sector', Tourism Management 27(4), 410-419. https://doi.org/10.1016/j. tourman.2004.10.006

Dick, A.S. \& Basu, K., 1994, 'Customer loyalty: Towards an integrated framework', Journal of the Academy of Marketing Science 22(2), 99-113. https://doi. org/10.1177/0092070394222001

Dong, B., Sivakumar, K., Evans, K.R. \& Zou, S., 2015, 'Effect of customer participation on service outcomes: The moderating role of participation readiness', Journal of Service Research 18(2), 160-176. https://doi.org/10.1177/1094670514551727

El-Manstrly, D., 2016, 'Enhancing customer loyalty: Critical switching cost factors', Journal of Service Management 27(2), 144-169. https://doi.org/10.1108/JOSM09-2015-0291

Ganesh, J., Arnold, M.J. \& Reynolds, K.E., 2000, 'Understanding the customer base of service providers: An examination of the differences between switchers and service providers: An examination of the differences between switchers and
stayers', Journal of Marketing 64(3), 65-87. https://doi.org/10.1509/ jmkg.64.3.65.18028

Gazley, A., Hunt, A. \& McLaren, L., 2015, 'The effects of location-based services on consumer purchase intention at point of purchase', European Journal of Marketing 49(9/10), 1686-1708. https://doi.org/10.1108/EJM-01-2014-0012

Gummesson, E., 2008, 'Quality, service-dominant logic and many-to-many marketing', The TQM Journal 20(2), 143-153. https://doi.org/10.1108/17542730810857372

Gutman, J., 1982, 'A means-end chain model based on consumer categorization processes', Journal of Marketing 46(2), 60-72. https://doi.org/10.2307/3203341

Gwinner, K.P., Gremler, D.D. \& Bitner, M.J., 1998, 'Relational benefits in services industries: The customer's perspective', Journal of the Academy of Marketing Science 26(2), 101-114. https://doi.org/10.1177/0092070398262002

Hasan, S.F.E., Mortimer, G., Lings, I.N. \& Neale, L., 2017, 'Examining the antecedents and consequences of gratitude', Journal of Services Marketing 31(1), 34-47. https://doi.org/10.1108/JSM-01-2016-0048

Hennig-Thurau, T., Gwinner, K.P. \& Gremler, D.D., 2002, 'Understanding relationship marketing outcomes: An integration of relational benefits and relationship marketing outcomes: An integration of relational benefits and relationship
quality', Journal of Service Research 4(3), 230-247. https://doi. quality', Journal of Service
org/10.1177/1094670502004003006

Holbrook, M.B. \& Hirschman, E.C., 1982, 'The experiential aspects of consumption: Consumer fantasies, feelings, and fun', Journal of Consumer Research 9(2), 132140. https://doi.org/10.1086/208906

Hollebeek, L.D., 2013, 'The customer engagement/value interface: An exploratory investigation', Australasian Marketing Journal 21(1), 17-24. https://doi. org/10.1016/j.ausmj.2012.08.006

Konovsky, M.A. \& Pugh, S.D., 1994, 'Citizenship behavior and social exchange' Academy of ManagementJournal37(3), 656-669. https://doi.org/10.2307/256704

Korneliussen, T. \& Greenacre, M., 2017, 'Information sources used by European tourists: A cross-national study', Journal of Travel Research 57(2), 193-205 (First published online date: 30 January 2017). https://doi.org/10.1177/004728751 6686426

Kumar, V. \& Reinartz, W., 2016, 'Creating enduring customer value', Journal of Marketing 80(6), 36-68. https://doi.org/10.1509/jm.15.0414

Kuo, Y.-F. \& Feng, L.-H., 2013, 'Relationships among community interaction characteristics, perceived benefits, community commitment, and oppositional brand loyalty in online brand communities', International Journal of Information Management 33, 948-962. https://doi.org/10.1016/j.jijinfomgt.2013.08.005

Lam, B., 2016, 'Who uses a travel agent in this day and age?', The Atlantic, 22 June, viewed 20 April 2017, from https://www.theatlantic.com/business/archive/2016/ 06/travel-agent/488282/
Lam, R. \& Burton, S., 2006, 'SME banking loyalty (and disloyalty): A qualitative study in Hong Kong', International Journal of Bank Marketing 24(1), 37-52. https://doi. org/10.1108/02652320610642335

Lam, S.Y., Shankar, V., Erramilli, M.K. \& Murthy, B., 2004, 'Customer value, satisfaction, loyalty, and switching costs: An illustration from a business-to-business service context', Journal of the Academy of Marketing Science 32(3), 293-311. https:// doi.org/10.1177/0092070304263330

Lam, T. \& Zhang, H., 1999, 'Service quality of travel agents: The case of travel agents in Hong Kong', Tourism Management 20(3), 341-349. https://doi.org/10.1016/ S0261-5177(98)00118-6

Lawler, E. \& Thye, S., 1999, 'Bringing emotions into social exchange theory', Annua Review of Sociology 25, 217-244. https://doi.org/10.1146/annurev.soc.25.1.217

Lin, J., Lobo, A. \& Leckie, C., 2017, 'The role of benefits and transparency in shaping consumers' green perceived value, self-brand connection and brand loyalty', Journal of Retailing and Consumer Services 35, 133-141. https://doi. org/10.1016/j.jretconser.2016.12.011

Markin, R.J., 1979, 'The role of rationalization in consumer decision processes: A revisionist approach to consumer behavior', Journal of the Academy of Marketing Science 7(4), 316-334. https://doi.org/10.1007/BF02729682

McCarthy, A., 2016, 'Why millennials are using travel agents to make their holiday planning easier', Lonely Planet Travel News, 21 November, viewed 20 April 2017 from http://www.lonelyplanet.com/news/2016/11/21/millennials-using-travelagents/

McColl-Kennedy, J.R., Sweeney, J.C., Soutar, G.N. \& Amonini, C., 2008, 'Professional service firms are relationship marketers: But does size matter?', Australasian
Marketing Journal 16(1), 30-47. https://doi.org/10.1016/S1441-3582(08)70003-X

Melnyk, V., van Osselaer, S. \& Bijmolt, T., 2009, 'Are women more loyal customers than men? Gender differences in loyalty to firms and individual service providers', Journal of Marketing 73(4), 82-96. https://doi.org/10.1509/jmkg.73.4.82

Millan, A. \& Esteban, A., 2004, 'Development of a multiple-item scale for measuring customer satisfaction in travel agencies services', Tourism Management 25(5), 533-546. https://doi.org/10.1016/j.tourman.2003.07.002

Mimouni-Chaabane, A. \& Volle, P., 2010, 'Perceived benefits of loyalty programs: Scale development and implications for relational strategies', Journal of Business Research 63(1), 32-37. https://doi.org/10.1016/j.jbusres.2009.01.008

Narayandas, D., 2005, 'Building loyalty in business markets', Harvard Business Review 83(9), 131-139.

Nguyen, N. \& Leblanc, G., 2001, 'Corporate image and corporate reputation in customers' retention decisions in services', Journal of Retailing and Consumer Services 8(4), 227-236. https://doi.org/10.1016/S0969-6989(00)00029-1

Nikbin, D. \& Hyun, S.S., 2015, 'An empirical study of the role of failure severity in service recovery evaluation in the context of the airline industry', Review of Managerial Science 9(4), 731-749. https://doi.org/10.1007/s11846-014-0135-7

Nilson, T.H., 1992, Value-added marketing: Marketing management for superior results, McGraw- Hill, Berkshire, UK.

Nilsson, D., 2007, 'Internet banking and the impact of seller support and third party', Journal of Internet Banking and Commerce 12(1), 1-9.

Nunkoo, R. \& Ramkissoon, H., 2013, 'Travelers' e-purchase intent of tourism products and services', Journal of Hospitality Marketing \& Management 22(5), 505-529. https://doi.org/10.1080/19368623.2012.680240

Nunnally, J.C., \& Bernstein, I.H., 1994, Psychometric theory, 3rd edn., McGraw-Hill, Inc, New York.

Oates, G., 2015, 'Travel agent industry executives argue that agents are coming back' Skift, 03 February, viewed 20 April 2017, from https://skift.com/2015/02/03/ travel-agent-industry-executives-argue-that-agents-are-coming-back/.

Oh, H., 1999, 'Service quality, customer satisfaction, and customer value: A holistic perspective', International Journal of Hospitality Management 18(1), 67-82. perspective', International Journal of Hospitality
$\mathrm{https} / / /$ doi.org/10.1016/S0278-4319(98)00047-4

Olenski, S., 2015, 'Are OTA's really killing brick and mortar travel agencies?', Forbes, 27 April, viewed 20 April 2017, from https://www.forbes.com/sites/ steveolenski/2015/04/27/are-otas-really-killing-brick-and-mortar-travelagencies/\#271cd94011d7

Ostrom, A. \& lacobucci, D., 1995, 'Consumer trade-offs and the evaluation of services', Journal of Marketing 59(1), 17-28. https://doi.org/10.2307/1252011

Parasuraman, A., Zeithaml, V.A. \& Berry, L.L., 1991, 'Refinement and reassessment of the SERVQUAL scale', Journal of Retailing 67(4), 420-450.

Petrick, J.F., 2002, 'Development of a multi-dimensional scale for measuring the perceived value of a service', Journal of Leisure Research 34(2), 119-134. https:// doi.org/10.1080/00222216.2002.11949965

Plewa, C., Sweeney, J.C. \& Michayluk, D., 2015, 'Determining value in a complex service setting', Journal of Service Theory and Practice 25(5), 568-591. https:// doi.org/10.1108/JSTP-03-2014-0059

Reichheld, F.F., 1996, The loyalty effect, Harvard Business School Press, Boston, MA.

Rintamäki, T., Kanto, A., Kuusela, H. \& Spence, M.T., 2006, 'Decomposing the value of department store shopping into utilitarian, hedonic and social dimensions: Evidence from Finland', International Journal of Retail \& Distribution Management 34(1), 6-24. https://doi.org/10.1108/09590550610642792

Roos, I. \& Gustafsson, A., 2007, 'Understanding frequent switching patterns', Journa of Service Research 10(1), 93-108. https://doi.org/10.1177/1094670507303232

Ryan, C. \& Cliff, A., 1997, 'Do travel agencies measure up to customer expectation? An empirical investigation of travel agencies' service quality as measured by SERVQUAL', Journal of Travel \& Tourism Marketing 6(2), 1-31. https://doi. org/10.1300/J073v06n02_01 
Sabiote-Ortiz, C.M., Frías-Jamilena, D.M. \& Castañeda-García, J.A., 2016, 'Overall perceived value of a tourism service delivered via different media: A cross-cultural perceived value of a tourism service delivered via different media: A cross-cultural
perspective', Journal of Travel Research 55(1), 34-51. https://doi. perspective', Journal of Travel
org/10.1177/0047287514535844

Sánchez-Fernández, R. \& Bonillo, M.A.I., 2007, 'The concept of perceived value: A systematic review of the research', Marketing Theory 7(4), 427-451. https://doi. org $/ 10.1177 / 1470593107083165$

Schwaiger, M., 2004, 'Components and parameters of corporate reputation - An empirical study', Schmalenbach Business Review 56, 46-71. https://doi. org/10.1007/BF03396685

Settoon, R.P., Bennett, N. \& Liden, R.C., 1996, 'Social exchange in organizations: Perceived organizational support, leader-member exchange, and employe reciprocity', Journal of Applied Psychology 81(3), 219-227. https://doi. org/10.1037/0021-9010.81.3.219

Sierra, J.J. \& McQuitty, S., 2005, 'Service providers and customers: Social exchange theory and service loyalty', Journal of Services Marketing 19(6), 392-400. https:// doi.org/10.1108/08876040510620166

Slater, S. \& Narver, J., 1994, 'Does competitive environment moderate the market orientation - Performance relationship?', Journal of Marketing 58, 46-55. https:// doi.org/10.2307/1252250

Slater, S.F., 1997, 'Developing a customer value-based theory of the firm', Journal of the Academy of Marketing Science 25(2), 162-167. https://doi.org/10.1007/ BF02894352

Spielmann, N., Laroche, M. \& Borges, A., 2012, 'How service seasons the experience: Measuring hospitality servicescapes', International Journal of Hospitality Management 31(2), 360-368. https://doi.org/10.1016/j.ijhm.2011.06.001

Sweeney, J.C. \& Soutar, G.N., 2001, 'Consumer perceived value: The development of a multiple item scale', Journal of Retailing 77(2), 203-220. https://doi.org/10.1016/ S0022-4359(01)00041-0

Walsh, G. \& Beatty, S., 2007, 'Customer-based corporate reputation of a service firm: Scale development and validation', Journal of the Academy of Marketing Science 35(1), 127-143. https://doi.org/10.1007/s11747-007-0015-7
Walsh, G., Beatty, S.E. \& Shiu, E.M.K., 2009, 'The customer-based corporate reputation scale: Replication and short form', Journal of Business Research 62(10), 924-930. https://doi.org/10.1016/j.jbusres.2007.11.018

Wan, W.W.N., Luk, C., Fam, K., Wu, P. \& Chow, C.W.C., 2012, 'Interpersonal relationship, service quality, seller expertise: How important are they to adolescent consumers?', Psychology \& Marketing 29(5), 365-377. https://doi.org/10.1002/ mar.20527

Wang, H., Guo, X., Zhang, M., Wei, Q. \& Chen, G., 2016, 'Predicting the incremental benefits of online information search for heterogeneous consumers', Decision Sciences 47(5), 957-988. https://doi.org/10.1111/deci.12200

Watson, G.F., IV, Beck, J.T., Henderson, C.M. \& Palmatier, R.W., 2015, 'Building, measuring, and profiting from customer loyalty', Journal of the Academy of Marketing Science 43, 790-825. https://doi.org/10.1007/s11747-015-0439-4

Williams, A.P. \& Soutar, G.N., 2009, 'Value, satisfaction and behavioral intentions in an adventure tourism context', Annals of Tourism Research 36(3), 413-438. https:// doi.org/10.1016/j.annals.2009.02.002

Woodruff, R.B., 1997, 'Customer value: The next source of competitive advantage', Journal of the Academy of Marketing Science 25, 139-153. https://doi. org/10.1007/BF02894350

Woodruff, R.B. \& Flint, D.J., 2006, 'Marketing's service-dominant logic and customer value', in R.F. Lusch \& S.L. Vargo (eds.), The service-dominant logic of marketing: Dialog, debate, and directions, pp. 183-195, M.E. Sharpe, Armonk, NY.

Yi, Y. \& Gong, T., 2013, 'Customer value co-creation behaviour: Scale development and validation', Journal of Business Research 66(9), 1279-1284. https://doi. org/10.1016/j.jbusres.2012.02.026

Yi, Y. \& La, S., 2004, 'What influences the relationship between customer satisfaction and repurchase intention? Investigating the effects of adjusted expectations and customer loyalty', Psychology \& Marketing 21(5), 351-373. https://doi. org/10.1002/mar.20009

Zarrad, H. \& Debabi, M., 2012, 'Online purchasing intention: Factors and effects', International Business and Management 4(1), 37-47. 


\section{Appendix 1}

TABLE 1-A1: Customers' perceived benefits of using a travel agent.

Benefit

Some comments by customers

Customisation The travel agent makes it easier to travel because they do all the thinking work...

I know I can find better deals online but I prefer the convenience, time-saving, and first-hand experience of my travel agent. It's convenient and hassle free. I do expect to be able to phone my travel agent after-hours in the case of an emergency or have access to an after-hours service.

We use a smaller travel agency because they know our exact requirements, such as that we will not wait at an airport for more than $2 \mathrm{~h}$ and that we prefer aisle seats, and they always accommodate these needs. They will book these seats online for us $24 \mathrm{~h}$ before even if it is on a Saturday or Sunday.

I can have a conversation with my travel agent about my needs to obtain a logical and practical end product.

I do like to have a bit of flexibility in the itinerary so that during the trip I can change my mind a bit.

The ultimate thing is that the travel agent can recommend just the thing for you.

Expertise It is especially gratifying if the travel agent has had personal experience in the destination you wish to visit and can offer first-hand advice. Professionals know about more options therefore they reduce the chance that you will find something better too late if you search on your own.

I feel that there is too much information available [on the Internet] and I rely on the travel agent to sort through it.

It is extremely important that the travel agent chats to the customer after the trip to see what they loved about it or what went wrong, and then they can pass this information onto other customers.

Having options is a benefit of a travel agent.

My travel agent knows my personal tastes and needs, and she matches options to my needs. She knows what not to recommend.

Support If the trip needs to be cancelled or adapted, I will phone the travel agent to make the changes and pay the costs.

I rely on my travel agent to have an established network so that if things go wrong she can tap into her network and find a solution.

My travel agent has a contingency plan that I would never even have thought about.

Personal connection and personal service is important to us because when we encounter a problem we phone our travel agent rather than having to figure it out on our own.

Emotional They need to communicate what's going on and what problems they encounter.

When I participate in the planning of the trip I feel a sense of accomplishment which is part of the whole travelling experience for me. It's also very important that I don't feel stressed or unhappy during the planning because it is part of the holiday and it helps me to look forward to it instead of hindering that positive anticipation.

I feel that because we use the same travel agent she knows our personalities and provides options that suit us better.

I feel a sense of affiliation to her [travel agent] and that's where my loyalty stems from.

Financial Often our travel agent has found better deals for us.

They are very honest in their pricing. They will issue a quote but if they find a better price they will let us know. They are always looking for the best flight prices and this makes me feel like their top priority and that they have my best interests.

Although the Internet can get you cheaper options, the travel agent can get you better value for money because they are so in tune with what's going on in the travel industry and they know all about the deals and specials.

They can give advice considering characteristics you want like in the city centre within your price range. 


\section{Appendix 2}

TABLE 1-A2: Questionnaire used for data collection.

\begin{tabular}{|c|c|c|}
\hline Dimensions & Items & Source \\
\hline Convenience1 & Information provided by my travel agent made it easy for me to make decisions & Colwell et al. (2008) \\
\hline Customise1 & My travel agent is able to provide me with a customised end product/service & Coelho and Henseler (2012) \\
\hline Expertise1 & My travel agent provides me with relevant information & Auh et al. (2007) \\
\hline Emotion1 & When I plan a trip with my travel agent it reflects the kind of person I am & Rintamäki et al. (2006) \\
\hline Support1 & My travel agent provides assistance in the event of unforeseen circumstances & Lam and Zhang (1999) \\
\hline Financial1 & I get the best possible prices when I plan a trip with my travel agent & Gwinner et al. (1998) \\
\hline Loyalty1 & I have developed a good relationship with my travel agent & Walsh and Beatty (2007) \\
\hline Emotion2 & Planning a trip with my travel agent 'gets me away from it all' & Babin et al. (1994) \\
\hline Support2 & My travel agent successfully deals with changes to my travel plans & Nikbin and Hyun (2015) \\
\hline Financial2 & When I plan a trip with my travel agent I receive value for money & Sweeney and Soutar (2001) \\
\hline Satisfaction1 & Overall I am satisfied with my travel agent & Wang et al. (2016) \\
\hline Convenience2 & I can communicate with my travel agent through various ways & Colwell et al. (2008) \\
\hline Customise2 & I accomplish what I want to when I customise a trip with my travel agent & Babin et al. (1994) \\
\hline Expertise2 & My travel agent provides me with correct information & Auh et al. (2007) \\
\hline Support3 & My travel agent solves problems that arise when planning a trip & Caro and Garcia (2008) \\
\hline Financial3 & My travel agent finds me the best options within my budget & Self-generated item \\
\hline Reputation1 & My travel agent has a favourable reputation & Nguyen and Leblanc (2001) \\
\hline Emotion4 & Planning a trip with my travel agent feels like an escape from my daily life & Babin et al. (1994) \\
\hline Support4 & My travel agent successfully deals with cancellations to my travel plans & Boshoff (1999) \\
\hline Financial4 & Planning a trip with a travel agent is economical & Sweeney and Soutar (2001) \\
\hline Loyalty2 & I am loyal to my travel agent & Walsh et al. (2009) \\
\hline Convenience3 & My travel agent makes it easy to complete my purchase & Colwell et al. (2008) \\
\hline Emotion5 & Emotionally I prefer the exclusivity that my travel agent offers & Ryan and Cliff (1997) \\
\hline Expertise3 & My travel agent has the knowledge to answer my questions & Parasuraman, Zeithaml and Berry (1991) \\
\hline Support5 & My travel agent quickly handles queries related to my travel plans & Millan and Esteban (2004) \\
\hline Reputation2 & My travel agent is highly reputable & del Bosque et al. (2006) \\
\hline Customise3 & My input ensures that my travel agent takes my requirements into consideration & Bock, Mangus and Folse (2016) \\
\hline Emotion6 & My travel agent contributes to my anticipation for the trip & Self-generated item \\
\hline Emotion7 & Being involved in planning a successful trip with my travel agent enhances my self-esteem & Dong et al. (2015) \\
\hline Financial5 & When I plan trip with my travel agent I receive good financial value & Williams and Soutar (2009) \\
\hline Customise4 & I receive a personalised trip when I plan it with a travel agent & Bock et al. (2016) \\
\hline Expertise4 & I benefit from my travel agent's accumulated experiences & Millan and Esteban (2004) \\
\hline Emotion8 & My travel agent does things for me that he/she doesn't do for other customers & Gwinner et al. (1998) \\
\hline Support6 & My travel agent attends to the fine print regarding my travel plans & Millan and Esteban (2004) \\
\hline Financial6 & I get the most out of my money when I plan a trip with my travel agent & Petrick (2002) \\
\hline
\end{tabular}

\section{The following demographic information was also collected from respondents:}

Screening question: How often do you need a travel agent to assist you with your travel arrangements in a typical year?

\begin{tabular}{|l|l|l|l|l|l|} 
Never & Once a year & Twice a year & Thrice a year & Four times a year & More than four times a year \\
\hline
\end{tabular}

For how many years have you been using a travel agent to assist you in your travel arrangements?

\begin{tabular}{|l|l|l|l|}
\hline $1-2$ years & $3-5$ years & $6-10$ years & More than 10 years \\
\hline
\end{tabular}

Please indicate the categories of travel in which you participate:

\begin{tabular}{|l|l|l|}
\hline Leisure & Business & Leisure and business \\
\hline
\end{tabular}

Your gender:

\begin{tabular}{|l|l|}
\hline Male & Female \\
\hline
\end{tabular}

Your age category:

\begin{tabular}{|l|l|l|l|l|}
\hline $20-30$ years & $31-40$ years & $41-50$ years & $51-60$ years & 61 years and older \\
\hline
\end{tabular}




\section{Appendix 3}

TABLE 1-A3: Final items of the study.

\begin{tabular}{|c|c|c|}
\hline Benefit & New label & Former label \\
\hline \multicolumn{3}{|l|}{ Perceived financial benefits } \\
\hline When I plan a trip with my travel agent I receive good financial value. & Finance1 & Finan5 \\
\hline Planning a trip with a travel agent is economical. & Finance2 & Finan4 \\
\hline I get the best possible prices when I plan a trip with my travel agent. & Finance3 & Finan1 \\
\hline I get the most out of my money when I plan a trip with my travel agent. & Finance4 & Finan6 \\
\hline When I plan a trip with my travel agent I receive value for money. & Finance5 & Finan2 \\
\hline \multicolumn{3}{|l|}{ Perceived expertise benefits } \\
\hline My travel agent provides me with relevant information. & Prof1 & Exper1 \\
\hline My travel agent is able to provide me with a customised end product/service. & Prof2 & Cust1 \\
\hline My travel agent provides me with correct information. & Prof3 & Exper2 \\
\hline \multicolumn{3}{|l|}{ Perceived support benefits } \\
\hline My travel agent successfully deals with cancellations to my travel plans. & Support1 & Support4 \\
\hline My travel agent successfully deals with changes to my travel plans. & Support2 & Support2 \\
\hline My travel agent provides assistance in the event of unforeseen circumstances. & Support3 & Support1 \\
\hline Planning a trip with my travel agent truly feels like an escape from my daily life. & Emotion1 & Symb4 \\
\hline Being involved in planning a successful trip with my travel agent enhances my self-esteem. & Emotion2 & Symb7 \\
\hline I experience a sense of belonging when I plan a trip with my travel agent. & Emotion3 & Symb3 \\
\hline Emotionally I prefer the exclusivity that my travel agent offers. & Emotion4 & Symb5 \\
\hline My travel agent contributes to my anticipation for the trip. & Emotion5 & Symb6 \\
\hline
\end{tabular}

